University of Rhode Island

DigitalCommons@URI

Open Access Master's Theses

1981

\title{
Identification and Differentiation of Species in Cooked Meat by Vertical Plate Gel Electrophoresis
}

Hamad Al-Awfy

University of Rhode Island

Follow this and additional works at: https://digitalcommons.uri.edu/theses

\section{Recommended Citation}

Al-Awfy, Hamad, "Identification and Differentiation of Species in Cooked Meat by Vertical Plate Gel Electrophoresis" (1981). Open Access Master's Theses. Paper 1000.

https://digitalcommons.uri.edu/theses/1000

This Thesis is brought to you for free and open access by DigitalCommons@URI. It has been accepted for inclusion in Open Access Master's Theses by an authorized administrator of DigitalCommons@URI. For more information, please contact digitalcommons-group@uri.edu. 
IDENTIFICATION AND DIFFERENTIATION OF

SPECIES IN COOKED MEAT BY VERTICAL

PLATE GEL ELECTROPHORESIS

By

HAMAD AL-AWFY

A THESIS SUBMITTED IN PARTIAL FULFILLMENT OF THE REQUIREMENTS FOR THE DEGREE OF

MASTER OF SCIENCE

I N

FOOD SCIENCE AND NUTRITION

UNIVERSITY OF RHODE ISLAND

1981 


\section{MASTER OF SCIENCE THESIS \\ OF}

HAMAD AL-AWFY

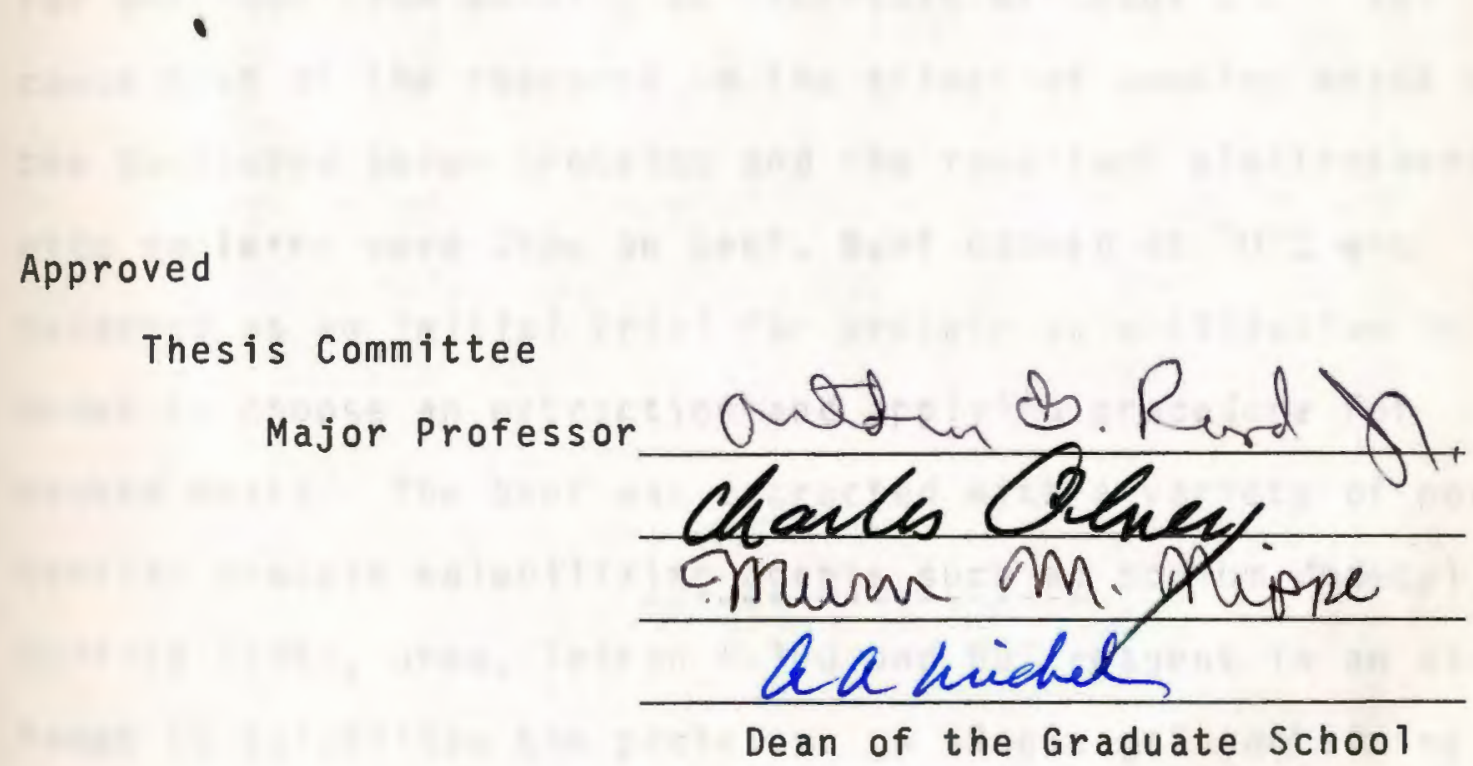

UNIVERSITY OF RHODE ISLAND 


\section{ABSTRACT}

Since quality control for adulteration in meat is very important, the vertical plate polyacrylamide gel electrophoretic technique was studied for the detection and identification of cookeld and canned species extracts.

Meat samples from beef, pork, $1 \mathrm{amb}$ and horse were heated for one hour from $65-75^{\circ} \mathrm{C}$ at intervals of about $5^{\circ} \mathrm{C}$. Because most of the research on the effect of cooking meats on the denatured serum proteins and the resultant electrophoretic patterns were done on beef, beef cooked at $70^{\circ} \mathrm{C}$ was selected as an initial trial for protein solubilization in order to choose an extraction and applying procedure for cooked meats. The beef was extracted with a variety of potential protein solubilizing agents such as sodium dodecyl sulfate (SDS), urea, Triton $X-100$ and $B D I$ reagent in an attempt to solubilize the proteins. A single gel containing urea or SDS in conjunction with a discontinuous buffer system was studied as the electrophoresis system. Amido black $10 B$ and Coomassie brilliant blue R-250 were compared as staining dyes. Constant power and constant voltage were compared as power supplies. Polyacrylamide gel electrofocusing was tried. Raw meat extracts were utilized as reference patterns. 
A system of tris-chloride buffer at pH 6.7 containing $2 M$ urea and $10 \%$ glucose gave the best resits as an extraction procedure. A single $7 \%$ cyanogum gel containing $4 \mathrm{M}$ urea in conjunction with a discontinuous buffer system was utilized as the electrophoresis system. Amido black was found to be more sensitive so it was selected as staining procedure. Also, additions of mercaptoethanol to the gel and sample improved the electrophoretic patterns. It was found that with constant power, the front solvent was a very sharp straight line and the bands were sharper than with constant voltage.

Characteristic differences were discernible between beef and lamb versus pork and horse meat heated at $65^{\circ} \mathrm{C}$, but the distinction was decreased with increasing temperature. Canned beef (corned beef) and mixture of canned pork and ham (SPAM) gave some bands but did not give proper separation of the bands. So with more study on solubility and gel electrophoretic patterns heat denatured proteins could be improved and achieved. Use of a densitometer might also improve the utility of the procedure.

Polyacrylamide gel electrofocusing did not work and that may be because the thickness of the gel which generates heat, or other causes, as discussed in Appendix $C$. 
I wish to express my sincere gratitude to Dr. Arthur G. Rand, of the Department of Food Science and Technology, Nutrition and Dietetics, for his guidance, valuable counsel, and $h$ is suggestions on the preparation and review of this thesis. I also would like to thank Dr. Charles E. Olney and Dr. Murn M. Nippo for serving on my thesis committee.

My sincere appreciation also goes to Dr. James Bergan for his advice, support, and encouragement during my study. Thanks are also due to my colleagues in the Department of Food Science and Nutrition at the University of Rhode Island for the wonderful moments which we have shared.

Appreciation is expressed to my Government for granting me a scholarship. I deeply thank the officials of our Ministry, CODOT, and the Saudi Arabian Educatioral Mission for their constant support and encouragement throughout this research. 
TABLE OF CONTENTS

PAGE

LIST OF TABLES. • . . . . . . . . . . . . . . . . . . . vi



MANUSCRIPT - Identification and differentiation of species in cooked meats by vertical

plate gel electrophoresis.

ABSTRACT. . . . . . . . . . . . . . 1

INTRODUCTIION. . . . . . . . . . . . . . . . . . 3

MATERIALS AND METHODS . . . . . . . . . . . 6

RESULTS AND DISCUSSION. . . . . . . . . . . . 14

REFERENCES ............... . . . 28

APPENDICES:

A. literature review . . . . . . . . . 30

B. SODIUM DODECYL SULFATE (SDS)-POLYACRYLAMIDE

GEL ELECTROPHORESIS. . . . . . . . . . 37

C. POLYACRYLAMIDE GEL ELECTROFOCUSING. • • . . 45

D. BIBLIOGRAPHY OF THE COMPLETE THESIS . . . 59 
1. Formulation for reagents used in vertical plate technique. . . . . . . . . 10

?2. Stock solutions used in SDS-polyacrylamide -gel electrophoresis. . . . . . . . 38

3. Composition of polyacrylamide gels of different concentration. . . . . . 4 42

4. Time in hours for electrophores is and isoelectric focusing in polyacrylamide gel............... . . 


\section{LIST OF FIGURES}

F IGURE

1 Electrophoretic pattern obtained from cookeld beef meat extracts comparing SDS based extraction media with buffer-glucose-urea (BGU)

2 Electrophoretic pattermobtained from cooked beef meat extracts comparing Triton $X-100$, urea, BDI and BGU extraction media.....

3 Ef'fect of urea concentration on cooked beef meat extracts.

4a Electrophoretic patterns obtained from cooked meats without addition of mercaptoethanol to the running gel.

4b Electrophoretic pattern obtained from cooked meats with addition of mercaptoethanol to the running ge?

5 Comparison between Amido black and Coomassie blue

6 Polyacrylamide electrophoretograms of raw and cooked meats

7 Polyacrylamide electrophoretograms of raw and cooked meats

8 Polyacrylamide electrophoretograms of raw and canned meats.......... . . 25

9 Polyacrylamide gel electrofocusing of raw, cooked and canned meats. 


\section{1}

\section{Preface}

This thesis has been prepared according to the manuscript thesis plan, following Journal of Food Science. 
Manuscript

Identification and Differentiation of Species in Cooked Meats by Vertical

Plate Gel Electrophores is 
Identification and differentiation of species in cooked meats by vertical plate gel electrophoresis.

\author{
H. A. AL-AWFY and A. G. RAND \\ Department of Food Science and \\ Technology, Nutrition and Dietetics \\ University of Rhode Is l and \\ ; Kingston, Rhode Is I and 02881
}

\title{
ABSTRACT
}

Since quality control for adulteration in meat is very important, the vertical plate polyacrylamide gel electrophoretic technique was studied for the detection and identification of cooked and canned species extracts.

Meat samples from beef, pork, lamb and horse meat were heated for one hour from $65-75^{\circ} \mathrm{C}$ at intervals of about $5^{\circ} \mathrm{C}$. Extractions were performed with a variety of potential protein solubilizing agents in an attempt to solubilize the proteins. Amido black $10 B$ and Coomassie brilliant blue R-150 were compared as staining dyes. Constant power and constant voltage were compared as power supplies. Raw meat extracts were utilized as reference patterns.

A system of tris-chloride buffer at $\mathrm{pH} 6.7$ containing $2 M$ urea and $10 \%$ glucose gave the best results as an extraction procedure. Amido black was found to be more sensitive. Also, addition of mercaptoethanol to the gel and sample improved the electrophoretic patterns. Constant power gave better resolution. 
Characteristic differences were discernible between beef and 1 amb versus pork and horse meat heated at $65^{\circ} \mathrm{C}$ but the distinction was decreased with increasing temperature. Canned meats did not give good resolution. 


\section{INTRODUCT I ON}

With increases in world population and the limited ability of growing animals to produce meat, meat prices continue to increase, especially some of the kinds which many people prefer (i.e., beef and 1amb).

Since quality control for adulteration in meat is very important, electrophoresis with polyacrylamide gel has been studied and successfully applied by Payne (1963) to raw products. This method, the disc polyacrylamide gel electrophoretic technique, developed by Ornstein (1964) and Davis (1964), has proven to be successful for separation and identification of animal serum proteins. Distinct electrophoretic patterns were obtained between meat and fish species using this technique (Payne, 1963; Mancusa, 1964).

The vertical plate polyacrylamide gel electrophoretic (VPE) technique, which was developed by Raymond (1964) has also been successfully used for the detection and identification of raw meat and fish species (Coduri and Rand, 1972a, 1972b).

The effect of cooking beef on the denatured serum proteins and on the resultant electrophoretic patterns has been studied. Laakkonen et al. (1970) found that changes in the electrophoretic patterns of bovine muscle took place during low temperature and long-time heating. Fogg and Harrison (1975) have studied the effect of two end points, 
$25^{\circ} \mathrm{C}$ and $45^{\star} \mathrm{C}$ in semitendinous beef muscle on the electrophoretic patterns of the sarcoplasmic proteins. They concluded that heating to $25^{\circ} \mathrm{C}$ decreased the number and intensity of the slowest migration protein components of the sarcoplasmic fraction and the effects were more pronounced at $45^{\circ} \mathrm{C}$. Lee et al. (1974) have employed polyacrylamide gel electrophoresis in the study of qualitative changes in electrophoretic patterns of water soluble protein extracts from bovine muscles cooked to final temperatures of $65,70,75,80,85$ and $90^{\circ} \mathrm{C}$. Thiey concluded that increments of cooking temperature caused a progressive weakening and disappearance of the electrophoretic bonds. Caldironi and Bazan (1980) reported that when beef muscles were cooked at temperatures between $60-80^{\circ} \mathrm{C}$, protein bonds gradually disappeared and could not be detected above $80^{\circ} \mathrm{C}$.

Deschrreider and Meaux (1974) stated that heating profoundly changed the electrophoretograms, but nevertheless allowed differentiation of various kinds of meat. Those authors reported that the disappearance of bands was precise in relation to temperature increase. Mafinen et al. (1979) reported that native and denatured meat proteins (pork, beef, chicken and turkey) were solubilized for polyacrylamide gel electrophoresis (PAGE) by SDS+Mercaptoethanol. SDS-PAGE patterns of each denatured sample resembled those of native samples, and all patterns of meat protein bands were so similar that species identification was impossible. 
This paper describes the study of vertical plate gel electrophoresis with urea as solubilizing agent for the potential separation and identification of protein from cooked/ canned meat, and the effect of meat cooking temperatures on the analysis of cooked/canned meat. 


\section{MATERIALS AND METHODS}

\section{Materials}

\section{Meat source.-}

Fresh and canned meats (beef, pork and lamb) were collected from a local market. Fresh horse meat was provided by $M$ and $R$ Company, Hartford, Connecticut.

\section{Reagents:-}

A 11 the reagents used in this experiment were obtained from Fisher Scientific Company, except mercaptoethanol and thymol which were obtained from Eastman Organic Chemicals, Tween 80 from Sigma Chemical Laboratories, Amido black 10B, Coomassie blue and bromophenol from Bio-Rad Laboratories, Cyanogum, TEMED and ammonium persulfate from E-C Apparatus Corporation and Triton $X-100$ from Hartman-Leddon Co. The

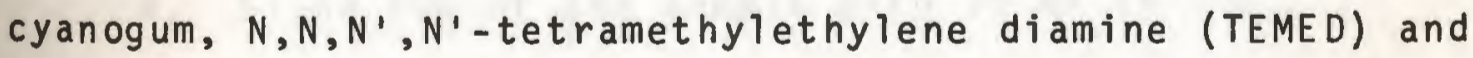
ammonium persulfate were stored under refrigeration. Deionized distilled water was used throughout.

\section{Equipment: -}

Vertical gel electrophoresis EC-470 Cell, EC-400 constant power supply, EC-454 constant voltage power supply, EC-225 diffusion destainer and an electrophoretic destainer, were purchased from EC Apparatus Co.

\section{Methods:-}

Cooked Meat protein solubilization 
ing meats on the denatured serum proteins and on the resultant electrophoretic patterns were done on beef, beef cooked at $70^{\circ} \mathrm{C}$ was selected as an initial trial for protein solubilization in order to choose an extraction and applying procedure for cooked meats, as follows:

Sample (beef) was put in a plastic bag and heated at $70^{\circ} \mathrm{C}$ in a water bath for one hour. Then extractions were performed with a variety of potential protein solubilizing agents.

1. Blend $20 \mathrm{~g}$ of the sample with $8 \mathrm{ml} 0.1 \%$ sodium 'dodecyl sulfate (SDS), $8 \mathrm{ml} 0.5 \mathrm{M}$ urea and $2 \mathrm{ml} 0.1 \%$ mercaptoethanol (ME). (SUM)

2. Blend $20 \mathrm{~g}$ of the sample with $15 \mathrm{ml} 2 \%$ SDS and $5 \mathrm{ml}$ of $1 \% \mathrm{ME}$. (SM)

3. Blend $20 \mathrm{~g}$ of the sample with $20 \mathrm{ml} 2 \% \mathrm{SDS}$. (SDS-1)

4. Blend $20 \mathrm{~g}$ of the sample with $20 \mathrm{ml} 2 \%$ SDS and heat it in a boiling water bath for 3 minutes. (Heat after blending.) (SDS-2)

5. Heat $20 \mathrm{~g}$ of the sample with $20 \mathrm{ml} 2 \%$ SDS in a boiling water bath for 3 minutes and blend (heat before blending). (SDS-3)

6. Blend $20 \mathrm{~g}$ of the sample with $5 \mathrm{ml} 3 \%$ Triton $\mathrm{X}-100$ and $15 \mathrm{ml} 1 \% \mathrm{ME}$.

7. Blend $20 \mathrm{~g}$ of the sample with $10 \mathrm{ml} 3 \%$ Triton $x-100$ and $10 \mathrm{ml} 7 \%$ SDS. 
8. Blend $20 \mathrm{~g}$ of the sample with $10 \mathrm{ml} 3 \%$ Triton $X-100$ and $10 \mathrm{ml} 0.5 \mathrm{M}$ urea.

9. Heat $15 \mathrm{~g}$ of the sample with $10 \mathrm{ml}$ of $B D I$ reagent $30 \mathrm{~g}$ of Triton $\mathrm{X}-100$ and $70 \mathrm{~g}$ of sodium tetraphosphate made up to one liter with distilled water (Thomas et al., 1955) in boiling water bath for 15 minutes and blend. (BDI)

10. Blend $50 \mathrm{~g}$ of the sample with $25 \mathrm{ml}$ tris(2-Amino2-hydroxymethyl-1,3-proponediol)-chloride buffer at $\mathrm{pH} 6.7$ containing $2 \mathrm{M}$ urea - $10 \%$ glucose $-0.2 \%$ mercaptoethanol. (BGU)

11. $10 \mathrm{~g}$ sample + 10M urea (ultra pure urea) was prepared according to Krzynowek and Wiggin (1979). (U)

Each mixture was transferred to a $50 \mathrm{ml}$ plastic centrifuge tube and centrifuged in a Sorvall $R C-2 B$ refrigerated centrifuge at 6000 RPM for 20-30 minutes. The supernatants were filtered through Whatman \# 1 filter paper. The density of each solution, for introduction into the slots of the electrophoretic gel, was improved with the addition of $0.1-$ $0.25 \mathrm{~g}$ of glucose per $\mathrm{ml}$ of supernatant. A crystal of thymol was added for preservation, and the samples were stored at $2^{\circ} \mathrm{C}$ until utilized.

Raw Meat:

Raw meat extracts were utilized as reference patterns, and the solutions were prepared as described by Coduri and Rand (1972a). 


\section{Processed Meat:}

Samples of individual meats were put in plastic bags and heated to $65^{\circ}, 70^{\circ}$ and $75^{\circ} \mathrm{C}$ in a water bath for one hour; the samples were left to cool down at room temperature for more than one hour. This meat was extracted for analysis or frozen for later use. Canned meats which contained various additives were washed several times with distilled water to minimize possible interference.

Heat processed meats were prepared for electrophores is by mixing $60 \mathrm{~g}$ with $25 \mathrm{ml}$ of extraction buffer at low speed for $30 \mathrm{sec}$ in a jacketed Waring Blendor jar surrounded with ice to prevent heat generation. The samples were blended at high speed until a uniform mixture was obtained. The blended samples were transferred to $50 \mathrm{ml}$ centrifuge tubes and clarified at $6000 \mathrm{rpm}$ for 20-30 min in a Sorval RC-2B refrigerated centrifuge. The supernatants were filtered through whatman \# 1 filter paper. The density of the samples, for introduction into the slots of the electrophoretic gel, were improved with the addition of $0.1 \mathrm{~g} / \mathrm{ml}$ of glucose. A crystal of thymol was added for preservation, and the samples were stored at $1^{\circ} \mathrm{C}$ until utilized.

\section{a-polyacrylamide Gel Electrophoresis:}

The vertical plate polyacrylamide gel electrophoretic technique described by Coduri and Rand (1972a) for the differentiation of meat speces was used with some modification. Formulation for all reagents used in this method are shown in Table 1 . 
Table 1

Reagent Formulation for VPE Method

1 - Extraction buffer

$\begin{array}{ll}\text { Tris } & 0.6 \mathrm{~g} \\ \text { Glucose } & 5.0 \mathrm{~g} \\ \text { Urea } & 6.0 \mathrm{~g} \\ \text { ME } & 0.1 \mathrm{ml}\end{array}$

$3 \mathrm{~N} \mathrm{HCl}$ to $\mathrm{pH} 6.7$

distilled water to make $50 \mathrm{ml}$

2- Gel solution

Tris

Cyanogum

Urea

TEMED

$3.5 \mathrm{~g}$

$10.5 \mathrm{~g}$

$36.0 \mathrm{~g}$

$0.15 \mathrm{ml}$

Ammonium persulphate $0.13 \mathrm{~g}$

Tween $80(10 \%)$

$0.2 \mathrm{mi}$

$3 \mathrm{~N} \mathrm{HCl} \mathrm{to} \mathrm{pH} 8.9$

distilled water to make $150 \mathrm{ml}$

3 - Electrode buffer

Tris

Glycine

$3.0 \mathrm{~g}$

distilled water to make $2 \mathrm{~L}, \mathrm{pH} 8.3$

4 - Stain

$\begin{array}{lr}\text { Amido black } & 2 \mathrm{~g} \\ \text { Methanol } & 100 \mathrm{ml} \\ \text { Glacial acetic } & \\ \begin{array}{l}\text { acid } \\ \text { Water }\end{array} & 30 \mathrm{ml} \\ & 100 \mathrm{ml}\end{array}$




\section{Gel Preparation}

The gel solution was prepared prior to each run, according to the formulation shown in Table 1. The tris, Cyanogum, urea and TEMED were dissolved in $90 \mathrm{ml}$ of water and adjusted to $\mathrm{pH} 8.9$ with $3 \mathrm{~N} \mathrm{HCl}$, followed by filtration through Whatman \# f filter paper. The volume of the gel solution was adjusted to $150 \mathrm{ml}$, and $0.2 \mathrm{ml}$ of $10 \%$ Tween $80,0.1 \mathrm{ml}$ mercaptoethanol and $0.13 \mathrm{~g}$ of ammonium persulfate were added with gentle agitation on a magnetic stirrer. The gel solution was poured at room temperature into an EC Apparatus Co. EC-470 vertical electrophoresis cell which was assembled horizoinally. A slot form for 10 samples was inserted, and the gel solution allowed to solidify for 40-50 min. The cell was then connected to a circulating refrigerated water bath, and coolant at $10^{\circ} \mathrm{C}$ was introduced into the cooling plates. The temperature in the refrigerated waterbath was reduced to $0^{\circ} \mathrm{C}$ over a 1 hour period and maintained at that temperature for the balance of the run. The excess gel above the slot form was removed and the cell was placed in a vertical position. The tris-glycine electrode buffer, precooled overnight to $2^{\circ} \mathrm{C}$ was added to the cell and allowed to overflow into the lowest chamber. The slot form was then carefully removed, and bromophenol blue was added to the buffer in the upper chamber to mark the position of the glycine-chloride front.

\section{Conditions for Electrophoresis}

1 - Constant Voltage - Was carried out as described by Coduri and Rand (1972a). 
2 - Constant Power. - The electrophoretic cell was connected to an EC Apparatus Co. EC 400 constant power supply with the lower electrode as positive, and a prerun at 20 watts for 15 min. was carried out until the front had entered the top of the slots. A $50 \mathrm{ul}(0.05 \mathrm{ml})$ aliquot of each sample was carefully added to the slots, underneath the electrcde buffer, with a glass syringe. An initial potential of 10 watts $(50 \mathrm{ma})$ was applied until the front had cleared the slots $(30 \mathrm{~min}$.$) . The potential was then$ increased to 20 watts for about 1.5 hour until the front migrated $10 \mathrm{~cm}$ from the bottom of the slots.

\section{Staining and Destaining}

After completion of the run, the power was turned off and the cell was disconnected. The electrode buffer was drained off and the cell was disassembled. The gel was removed and stained for 15 minutes in the Amido black $10 B$ stain shown in Table 1, with gentle shaking. Destaining was accomplished first by gently shaking the gel in a 50-50 mixture $(v / v)$ of methanol and $5 \%$ acetic acid for 15 min to remove readily soluble dye, and then by transferring to destainer to clean the gel. An electrophoretic destainer which cleared the patterns in about $45 \mathrm{~min}$. at 3.0 amps with $7 \%$ acetic acid recirculated over charcoal was used initially, but electrophoretic destaining was not recommended because the process caused substantial loss of the protein dye complex (Ahmadi, 1979). The preferred method employed an E-C 
Apparatus (EC-225) diffusion destainer which cleared the patterns in about 8-10 hours with a mixture of $5: 5: 1$ (v/v) water, methanol, and glacial acetic acid recirculated over charcoal.

\section{Photography}

Amido black stained gels were photographed using background lighting on Polaroid 3000 speed black and white land pack film type $107 \mathrm{C}$, employing a Polaroid CU-5 camera. 


\section{RESULTS AND DISCUSSION}

In the initial trials, beef cooked at about $70^{\circ} \mathrm{C}$ was extracted with different solutions in an attempt to solubilize the proteins. Figures 1 and 2 show the effect of different extraction solutions on the electrophoretic patterns. As seen in Figure 1, cooked beef extraction with SDS only without heating (SDS-1), SDS with heating after blending (SDS-2), SDS with heating before blending (SDS-3) and SDS with mercaptoethanol (SM), all gave faint bands, whereas combination of SDS, urea and mercaptoethanol enhanced the appearance of the bands; but tris-HCl buffer containing $2 M$ urea and $10 \%$ glucose (BGU) improved the occurrence and sharpness of the bands. As shown in Figure 2 cooked beef extracted with Triton-X-100 with mercaptoethanol (TM), Triton X-100 with SDS (TS), Triton X-100 with urea (TU) and BDI reagent all give very faint bands, whereas $10 \mathrm{M}$ urea gave bands but did not give proper separation of the bands. Those figures show tris-HCl buffer containing $2 \mathrm{M}$ urea and $10 \%$ glucose (BGU) produced electrophoretic patterns which were better and more sharply defined than other extraction media.

The concentration of urea in the extraction buffer was examined to select the optimum concentration. As shown in Figure 3, with a cooked beef meat heated to about $70^{\circ} \mathrm{C}$, $6 \mathrm{M}$ and $8 M$ urea did not give proper separation of the bands, whereas $1 M, 2 M$ and $4 M$ urea gave excellent migration. The optimum extraction concentration appeared to be $2 M$ urea with 


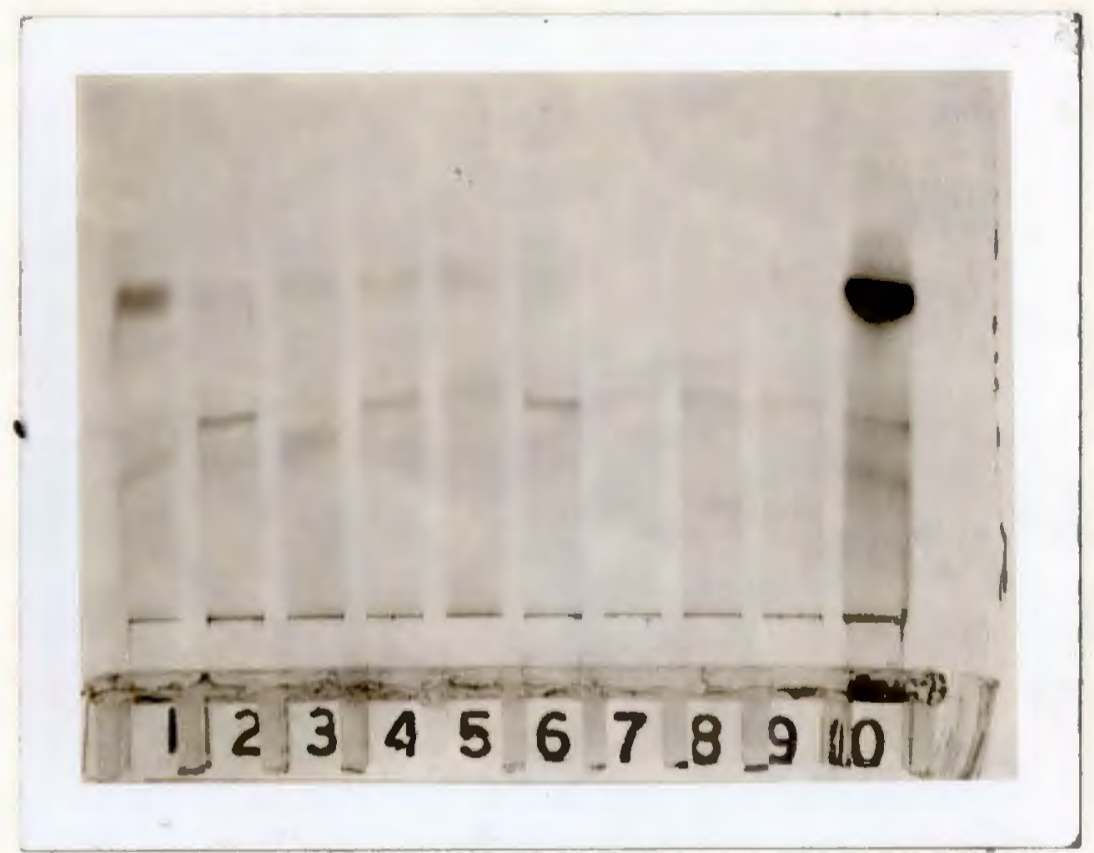

Figure 1. Electrophoretic patterns obtained from cooked beef meat extracts comparing SDS based extraction media with buffer-glucoseurea (BGU)

Samples :

(1) SUM, (2 and 4) MS, (3 and 5) SDS-1 (6 and 8) SDS-2, (7 and 9) SDS-3 (10) BGU 


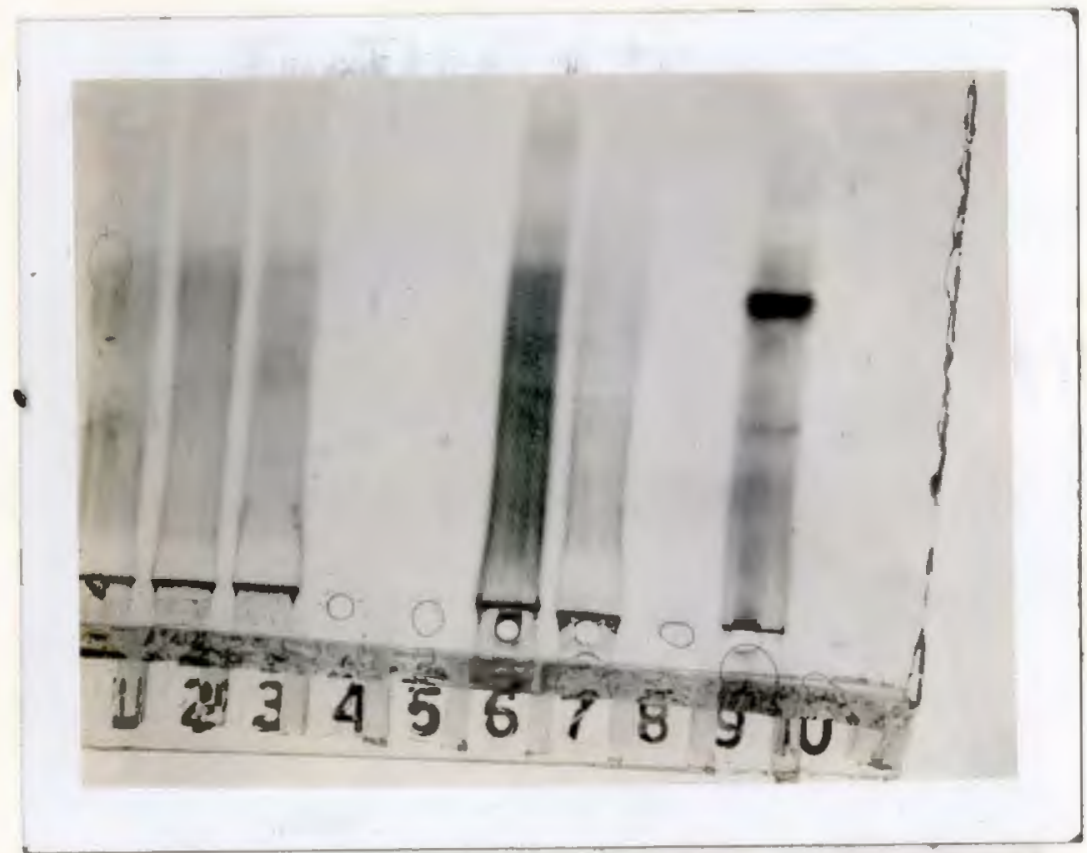

Figure 2. Electrophoretic patterns obtained from cooked meat extracts comparing Triton $\mathrm{X}-100$, urea, BDI and BGU extraction media.

(1) Triton X-100 with ME (TM), (2) Triton X-100 with SDS (TS), (3) Triton X-100 with urea (TU), (6) 10M urea (U), (7) BDI reagents, (9) tris-HCl buffer containing 2M urea and $10 \%$ glucose (BGU). 




Figure 3. Effect of urea concentration on cooked beef meat extracts, in presence of mercaptoethanol.

(1) 1M urea, (2) $2 \mathrm{M}$ urea, (3) $4 \mathrm{M}$ urea, (4) 6M urea, (5) $8 \mathrm{M}$ urea, $(6,7) 2 \mathrm{M}$ urea without ME. 
mercaptoethanol which provided a slightly better pattern.

The addition of mercaptoethanol to the running gel was also studied. Figure 4 a shows electrophoretic patterns obtained from cooked meats without addition of mercaptoethanol to the running gel. Figure $4 b$ shows electrophoretic patterns obtained from the same extracts of cooked meats, but with addition of $0.1 \mathrm{ml}$ concentrated mercaptoethanol to the running gel. Those two figures indicated that addition of mercaptoethanol to the running gel improved the number of bands separated. Also different amounts $(0.2 \mathrm{ml}, 0.3 \mathrm{ml})$ of mercaptoethanol were tried to see if increasing and addition of mercaptoethanol to the running gel provided further improvement, but there was no change in the resolutions.

The effect of Amido black $10 B$ and Coomassie brilliant blue R-250 on the electrophores is of meat protein as a staining procedure was compared. Cooked beef meat extracted with extraction buffer containing $1 M, 2 M$ and $4 M$ urea containing mercaptoethanol and $2 M$ urea without mercaptoethanol were applied to a gel in duplicate. After the electrophoretic run was accomplished, the gel was divided down the middle. One side of it was stained in. Amido black $10 \mathrm{~B}$ according to Coduri and Rand (1972a). The other half of the gel was stained for one hour at $25^{\circ} \mathrm{C}$ with $0.1 \%$ Coomassie brilliant blue solution freshly made up in $50 \%$ trichloroacetic acid and destained by repeated washing in $10 \%$ acetic acid for approximately 48 hours (Ogita and Markert, 1979). As seen in Figure 5, Amido black was sensitive and gave sharper 


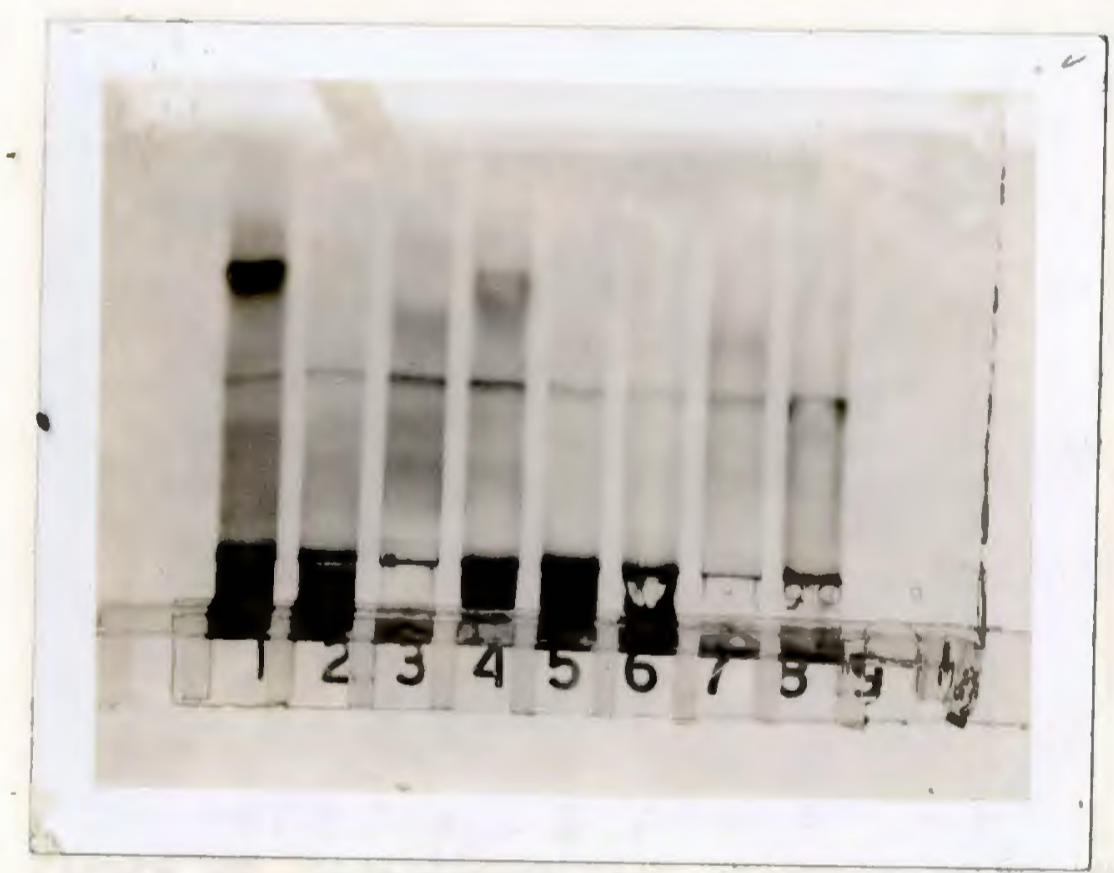

Figure 4a. Electrophoretic patterns obtained from cooked meats without addition of ME to the running gel.

Samples :

(1) Beef cooked at $70^{\circ} \mathrm{C}$ (2) Pork cooked at $70^{\circ} \mathrm{C}$ (3) Horsemeat cooked at $70 \mathrm{C}$ (4) Lamb cooked at $70^{\circ} \mathrm{C}$ (5) beef cooked at $75^{\circ} \mathrm{C}$ (6) Pork cooked at $75 \mathrm{C}$ (7) horse meat cooked at $75^{\circ} \mathrm{C}$ (8) Lamb cooked at $75^{\circ} \mathrm{C}$. 


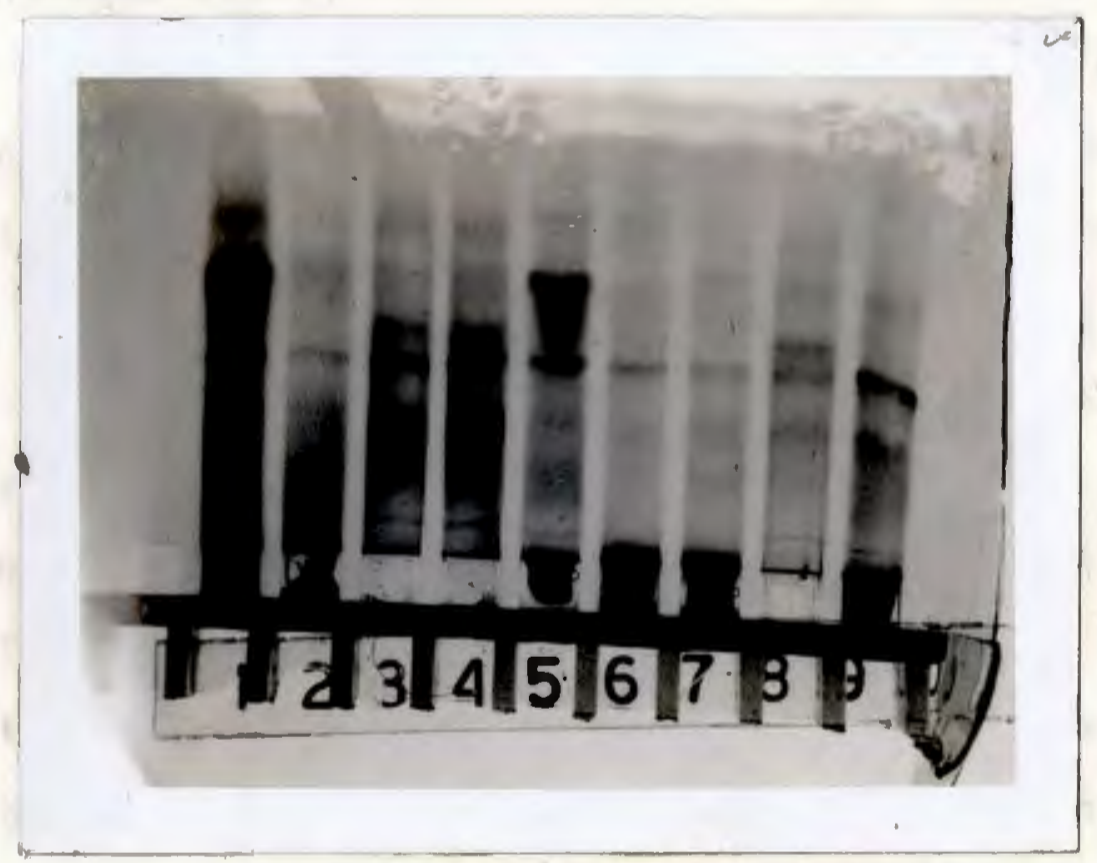

Figure 4b. Electrophoretic patterns obtained from cooked meats with addition of $0.1 \mathrm{ml}$ concentrated mercaptoethanol to the running gel.

Samples :

(1) Beef cooked at $70^{\circ} \mathrm{C}$ (2) Pork cooked at $70^{\circ}$ i" (3 and 4) Horse meat cooked at $70^{\circ} \mathrm{C}$ (5) Lamb cooked at $70^{\circ} \mathrm{C}$ (6) Beef cooked at $75^{\circ} \mathrm{C}$ (7) Pork cooked at $75^{\circ} \mathrm{C}$ (8) horse meat cooked at $75^{\circ} \mathrm{C}$ (9) Lamb cooked at $75^{\circ} \mathrm{C}$. 
resolution - better than Coomassie blue. Wilson (1979) also found the same results. Therefore, Amido black $10 \mathrm{~B}$ was selected as the stain of preference, following the procedure of Coduri and Rand (1972).

The effect of constant power (Figures 6,7 and 8 ) using a constant power supply was compared to the use of constant voltage in Figures $1,2,3,4 a, 4 b$ and 5 . It was found that the constant power the glycine-chloride front was a very sharp straight line, whereas in constant voltage the boundary was not always in a very straight line. The bands were sharper using constant power than constant voltage power. Also, the running time was cut from 3 hours to about 2 hours. Whereas the function of the constant power was to maintain mobility of the sample being separated and not overheat or underpower the separation nor require constant adjustments ( $E-C$ Apparatus Corporation), constant power was selected as the preferred method.

Employing the optimum extraction method developed (BGU), raw and cooked meats were analyzed by gel electrophoresis. Figures 6 and 7 show the effect of various cooking temperatures. At $65^{\circ} \mathrm{C}$ the fastest migrating protein band of beef became very weak and the intensity of the second band also decreased. The slowest disappeared but the thrid band did not change migrating; new secondary band appeared. The slowest migrating band of pork disappeared and the intensity of the fastest migrating band decreased. The intensity, visibility and sharpness of the two bands of lamb became more 


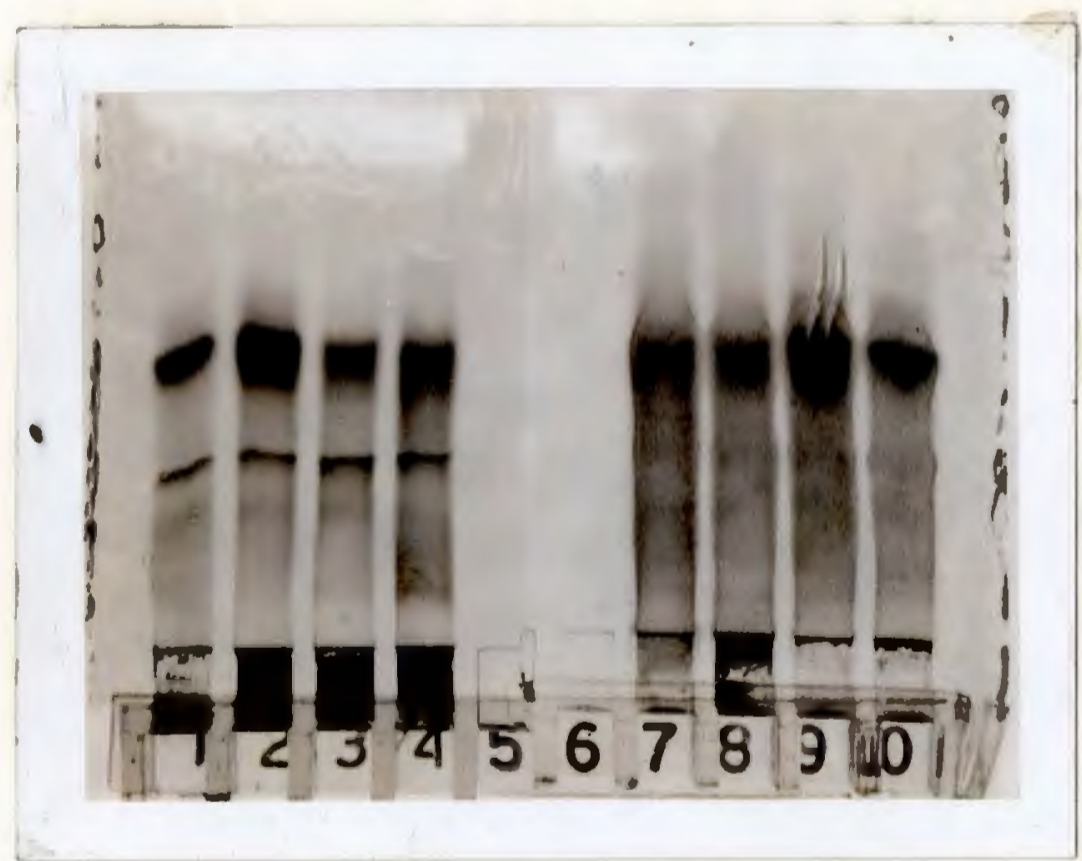

Figure 5. Comparison between Amido black $10 \mathrm{~B}$ and Coomassie brilliant blue R-250, as staining procedure.

Samples 1,2,3 and 4 stained with Amido black $10 \mathrm{~B} ; 7,8,9$, and 10 stained with Coomassie Blue. 


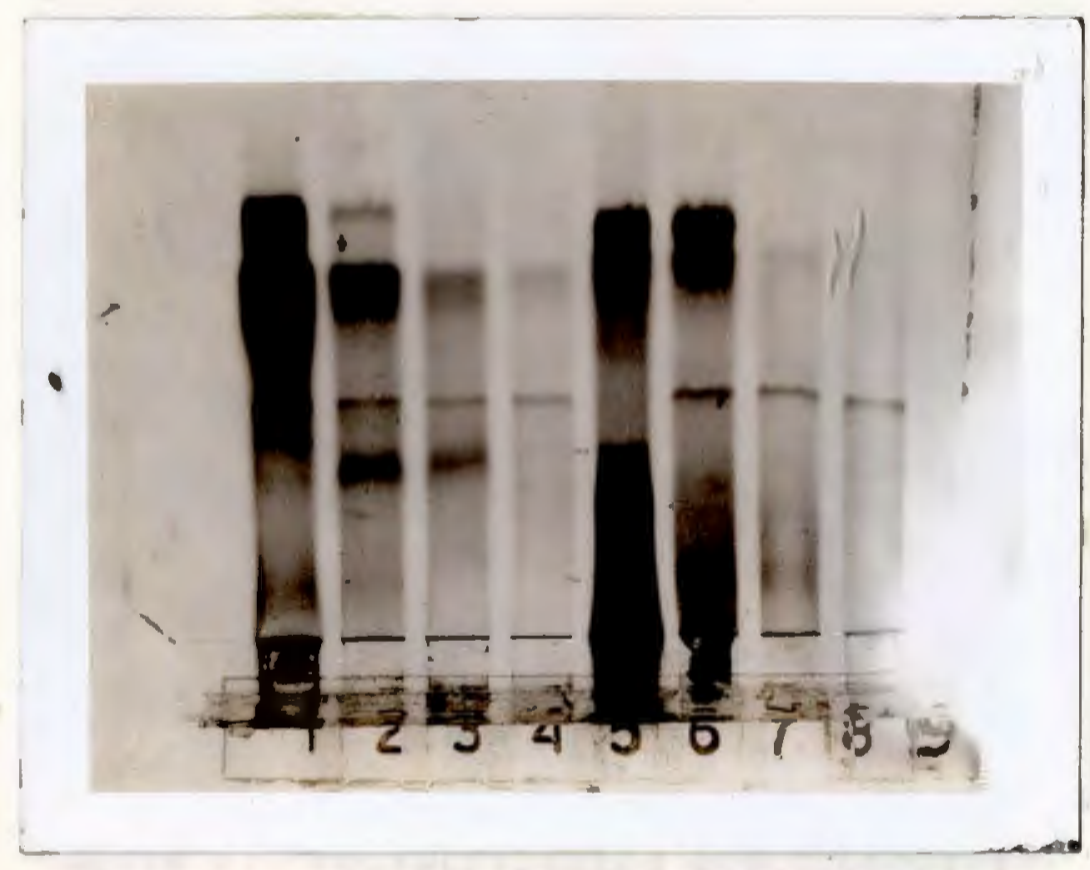

Figure 6. Polyacrylamide electrophoretograms of (1) raw beef, (2) beef cooked at $65^{\circ} \mathrm{C}$, (3) beef cooked at $70^{\circ} \mathrm{C}$, (4) beef cooked at $75^{\circ} \mathrm{C}$, (5) raw pork, (6) pork cooked at $65^{\circ} \mathrm{C}$, (7) pork cooked at $70^{\circ} \mathrm{C}$, and (8) pork cooked at $75^{\circ} \mathrm{C}$. 


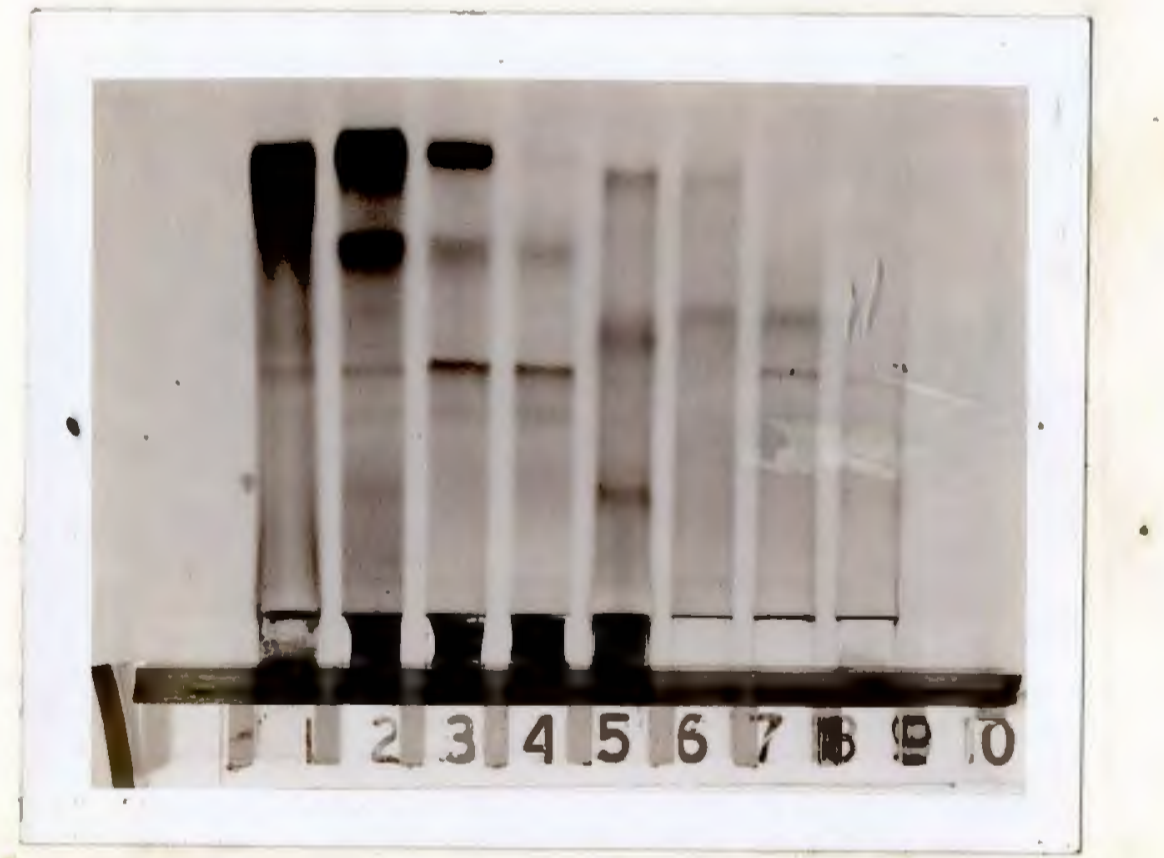

Figure 7. Polyacrylamide electrophoretograms of (1) raw lamb, (2) lamb cooked at $65^{\circ} \mathrm{C}$, (3) $1 \mathrm{amb}$ cooked at $70^{\circ} \mathrm{C}$, (4) $1 \mathrm{amb}$ cooked at $75^{\circ} \mathrm{C}$, (5) raw horse, (6) horse cooked at $65^{\circ} \mathrm{C},(7)$ horse cooked at $70^{\circ} \mathrm{C}$, and (8) horse cooked at $75^{\circ} \mathrm{C}$. 


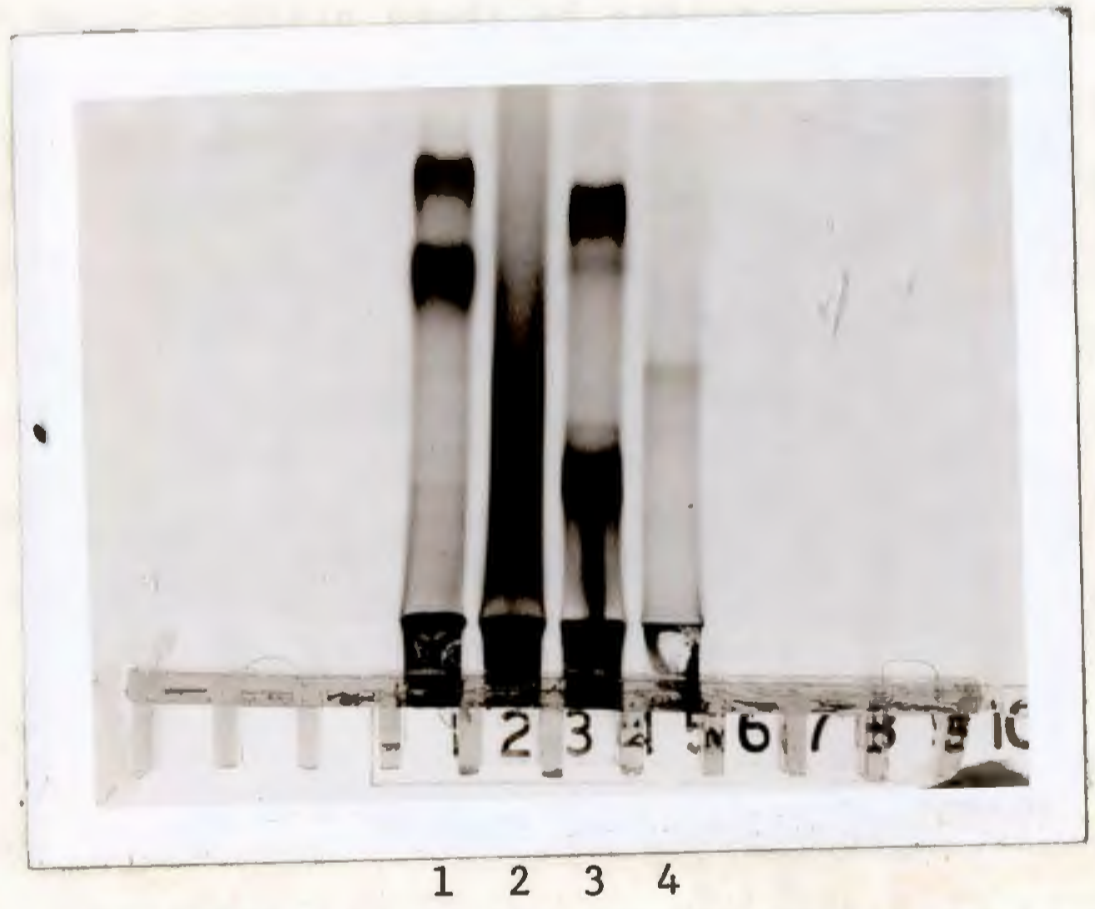

Figure 8. Polyacrylamide Electrophoretogram of raw and canned meats. (1) raw beef, (2) corned beef, (3) raw pork, and (4) canned pork and ham. 
obvious. The slowest migrating band of horse meat disappeared whereas the two highest migrating bands became lighter and in fact the second band may have begun to change or disappear.

The major protein bands of native horsemeat stained lighter than other meat extracts, and the reason may be that the volume of extraction material obtained from horse meat was greater than the amount recovered from the other meats. The possibility that the increased volume resulted in dilution of the soluble material and there may be less soluble material present in horse meat were considered as probable causes for the weaker staining of extraction containing horse meat (Coduri and Rand, 1972a).

At $70^{\circ} \mathrm{C}$, the fastest migrating bands of beef, pork and horse virtually disappeared, whereas lamb bands were less intensive. The intensity of the second migrating band of beef and lamb decreased to a great extent, while pork bands almost disappeared, but in the horse meat a new sharp band appeared.

At $75^{\circ} \mathrm{C}$ the fastest migrating band of all meats disappeared. The second band of pork and horse meat disappeared while beef and lamb were still present but very faint. Some new secondary bands appeared in both pork and horse. Figure 8 shows that canned beef (corned beef) gave some bands but did not give proper separation of the bands. A mixture of canned pork and ham (SPAM) gave very faint bands.

The increased sharpness and appearance of more bands 
after heating may be due to a low molecular weight fragment derived from one of the proteins initially present (Cohen, 1966).

These figures show the electrophoretic patterns obtained with VPE method using only one gel. Characteristic differences were discernible between beef and lamb versus pork and horse at $65^{\circ} \mathrm{C}$, but the distinction decreased with an increase of the heat process temperature. Therefore, this study did not agree with Mafinen et al. (1979) who reported that electrophoret ic patterns of each denatured sample resembled those of native samples, and all patterns of meat protein bands were so similar that species identification was impossible. However, these results agreed with Laakkonen et al. (1970), Fogg and Harrison (1975), Lee et al. (1974), Deschrreider and Meaux (1974), and Caldironi and Bizan. (1980) who reported that the disappearance of bands was precise in relation to temperature increase.

More study on solubility using different solubilizing agents and different concentrations and studying their chemistry (i.e. interaction with proteins) should be done to measure the denatured proteins. Using different gel media and gel electrophoresis techniques could improve the resolution and the appearance of the electrophoretic patterns. Use of a densitometer also might improve the differentiation and increase the detection of the light bands. 
References

Ahmadi, B. 1979. Recovery of protein from sodium dodecyl sulfate-polyacrylamide gels, Anal. Biochem. 97:229.

Caldironi, H.A. and Bazan, N.G. 1980. Quantitative determination of low-salt soluble protein patterns of bovine muscles cooked at different temperature by sodium dodecyl sulfate-polyacrylamide gel electrophoresis. J. Food Sci. 45: 901 .

Coduri, R.J. and Rand, A.G. 1972a. Vertical plate gel electrophoresis for the differentiation of meat species. J. Assoc. Off. Anal. Chem. 55:461.

Coduri, R.J.and Rand, A.G. 1972b. Vertical plate gel electrophoresis for the differentiation of fish and shellfish species. J. Assoc. Off. Anal. Chem. 55:464.

Cohen, E.H. 1966. Protein changes related to ham processing temperatures. 1. Effect of time-temperature on amount and composition of soluble proteins. J. Food Sci. 31:746.

Davis, B.J. 1964. Disc electrophoresis. II. Method and application to human serum proteins. Ann. N.Y. Acad. Sci. $121: 404$.

Deschrreider, A.R. and Meaux, R. 1974. Polyacrylamide gel electrophoresis of meat proteins. Industries Alimentaires et Agricales. 91:101 [Food Sci. Technol. Abstr. 2 So 182 $(1975)]$.

Fogg, N.E. and Harrison, D.L. 1975. Relationship of electrophoretic patterns and selected characteristics of bovine skeletal muscle and internal temperature. J. Food Sci. 40:28.

Laakkonen, E., Sherbon, J.W. and Wellington, G.W. 1970. Low temperature, long-time heating of bovine muscle. J. Food Sci. 35:178.

Lee, Y.B., Rickonsrud, D.A.,Hagberg, E.C. and Briskey, E.J. 1974. Application of SDS-acrylamide gel electrophoresis for determination of the maximum temperature to which bovine muscles have been cooked. J. Food Sci. 39:428.

Makanichi, A., Wreede, I. de; Stegemann, H., Henert, H.H. 1979. Solubility and gei electrophoretic patterns of heat denatured proteins, even from samples containing starch, after treatment with sodium dodecyl sulphate. Zeitschrift fur Lebensmittle-untersuchung und Forschung. 168:282 [Food Sci. Technol. Abstr.9 AO 651 (1979)]. 
Mancuso, V.M. 1964. Protein typing of some authentic fish species by disc electrophoresis. J. Assoc. Off. Anal. Chem. $47,5: 841$.

Ogita, Z. and Markert, C.L. 1979. A miniaturized system for electrophoresis on polyacrylamide gels. Anal. Biochem. $99: 233$.

Ornstein, I. 1964. Disc electrophoresis. I. Background and theory. Ann. N.Y. Acad. Sci. 121:321.

Payne, W.R. 1963. Protein typing of fish, pork and beef by disc electrophoresis. J. Assoc. Off. Ana1. Chem. 46:1003.

Raymond, S. 1964. Acrylamide gel electrophoresis. Ann. N.Y. Acad. Sci. 121:350.

Thomas, E.L., Nielsen, A.J. and Olson, J.C. 1955. Hydrolytic rancidity in milk - a simplified method for estimating the extent of its development. Am. Milk Rev., 17:50.

Wilson, Curtis M. 1979. Studies and Critique of Amido black $10 B$, Coomassie blue $R$, and fast green FCF as stains for proteins after polyacrylamide gel electrophoresis. Ana1. Biochem. 96:263. 
APPENDIX A LITERATURE REVIEW 


\section{LITERATURE REVIEW}

With the vast increase in world population and the limited ability of growing animals to produce meat, meat prices are getting higher day after day, especially some of the kinds which most of thiepeople prefer (i.e., beef and 1 amb). Fennema (1976) predicts that the industrialists will look more and more to areas of substituted, fabricated or synthetic foods as a possible solution to world food problems.

If these trends continue, the substitution of meats can be predicted in these new kinds of foods. Thus, the detection of any adulteration in ground and combined meats is one of the difficult problems which may arise in the examination of their purity,particularly when canned. The study of this problem is very important especially from the point of consumer protection, and religious considerations in some countries where pig meat is not allowed in any ratio. Protein analysis could be one of the logical solutions to differentiate meat products.

Whereas proteins are polyelectrolytes, polyvalent, high molecular weight ions, and the side chains of certain amino acids are the ionizable sites on simple proteins, so all soluble proteins are charged at some pH values within their range of stability and are therefore amenable to electrophoretic analysis. Various electrophoretic techniques such as: moving boundary electrophoresis, zone electrophore- 
sis, polyacrylamide gel electrophoresis and thin layer isoelectric focusing have been used for the separation and identification of proteins.

Since the quality control from any adulteration in meat is very important, electrophoresis with polyacrylamine gel has been successfully applied by Payne (1963) as a method for separation and identification of animal serum proteins using the disc polyacrylamide gel electrophoretic technique. As developed by Ornstein (1964) and Davis (1964), the method has proven to be a good method for the detection and identification of mixtures of animal proteins. Distinct electrophoretic patterns were obtained between meat and $f$ ish species using this technique (Payne, 1963; Mancuso, 1964). However, any possible application of the disc procedure for routine analysis of animal species would be hampered by the timeconsuming process and the many manipulations required. A separate gel must be prepared for each sample, making it difficult to maintain uniform conditions for all samples. Thus, visual comparisons of several samples for the detection of differences in electrophoretic patterns may not always be valid, or possible, and the procedure would not appear to be satisfactory for daily analytical work (Coduti and Rand, 1972a).

The vertical plate polyacrylamide gel electrophoretic (VPE) technique, which was developed by Raymond (1964) has also been a useful method for protein analysis. This technique is preferable in contrast to a disc technique for several reasons. (1) The flat slab provides maximum surface 
area for cooling the gel; (2) the resulting patterns are easier to quantitate in standard recording densitometers; (3) a large number of samples can be processed in a single gel, making the technique easier to carry out in the laboratory and facilitating the direct intercomparison of specimens processed under identical conditions all the way through to the final densitometer recording; (4) and most important, the flat slab permits the application of two-dimensional technique, which is impossible in the vertical tube apparatus (Raymond, 1964). Nakanichi and Raymond (1962) reported that VEP could be used in the routine process of blood proteins. Laakkonen et al. (1970) found this technique was useful for meat analysis.

Coduri and Rand (1972a) were the first to establish that distinct electrophoretic pattern could be obtained from the sarcoplasmic extracts of different meats -- beef, lamb, pork, and horse, using vertical plate technique. Also, they applied this technique for the differentiation on fish and shellfish species (1972b).

Coduri, Bonatti and Simpson (1979) applied a vertical plate gel electrophores is to the separation of pigmented and nonpigmented trout and salmon species.

In order to import meat from many countries of the world the mea. must be cooked to $69^{\circ} \mathrm{C}$ to insure destruction of the foot and mouth disease virus if present (Heidelbaugh and Graves, 1968), a number of methods therefore have been tried 
to determine the cooking temperature such as extractability, coagulation test, determination of acid phosphatase activity and direct spectroscopy of extracted meat pigments. Cohen (1966) studied the protein changes related to ham processing temperatures and found that the rate of theatng as well as the temperature reduced the amount of extractable proteins. In 1969 he studied the determination of acid phosphatase activity in canned hams as an indicator of temperatures attained during cooking. He found the method lacked accuracy when applied to hams processed to higher internal temperatures. Doesburg and Papendrof (1969) stated that the degree of heating of some fish muscle could be calculated from the coagulation test. Helmke and Froning (1971) studied the effect of endpoint cooking temperature on the color of turkey meat. They found that the extracted pigment from turkey meat, which was cooked to $82^{\circ} \mathrm{C}$, had a spectra quite different than that observed at lower temperatures.

None of these methods, however, has proved to be acceptable because they were only applicable to narrow ranges of cooking temperature or other experimental conditions.

Since cooked meat will be denatured and protein solubility will decrease, solubilizing agents such as urea and sodium dodecyl sulphate (SDS) are necessary to solubilize the protein in cooked meat. Since SDS and urea are two of the most commonly used reagents in protein chemistry, their applications in protein denaturation, solubilization, dissociation and purification are much too numerous to summarize here. 
An advantage of these agents is the ability to obtain constant electrophoretic mobilities of proteins independent of isoelectric point and amino acid composition, which can be slightly modified during cooking (Lee et al., 1974).

The effect of cooking beef on the denaturation of proteins and on the resultant electrophoretic patterns has been studied. Laakkonen et al. (1970) found that changes in the electrophoretic patterns of bovine muscle took place during low-temperature and long-time heating. Fogg and Harrison (1975) have studied the effect of two end points, $25^{\circ}$ and $45^{\circ} \mathrm{C}$ in semi-tendinous beef muscle on the electrophoretic patterns of the sarcoplasmic proteins. They conclude that heating to $25^{\circ} \mathrm{C}$ decreased the number and ilntensity of the slowest migration protein components of the sarcoplasmic fraction and that the effects were more pronounced at $45^{\circ} \mathrm{C}$. Lee et al. (1974) have employed polyacrylamide gel electrophoresis in the study of qualitative changes in electrophoretic patterns of water soluble protein extracts from bovine muscles cooked to final temperatures of $65,70,75,80,85$ and $90^{\circ} \mathrm{C}$. They concluded that increments of cooking temperature caused a progressive weakening and disappearance of the electrophoretic bands. Also, Calderoni and Bazan (1980) reported that when beef muscles were cooked at temperatures between $60-80^{\circ} \mathrm{C}$, protein bands gradually disappeared and could not be detected above $80^{\circ} \mathrm{C}$.

Deschrreider and Meaux (1974) stated that heating profoundly changed the electrophorograms of various kinds of 
meats. Those authors reported that the disappearance of bands was precise in relation to temperature increase. But Mafinen et al. (1979) reported that native and denatured meat proteins (pork, beef, chicken and turkey) were solubilized for polyacrylamide gel electrophoresis (PAGE) by SDS + Mercaptoethanol. SDS-PAGE patterns of each denatured sample resembled those of native samples, and all patterns of meat protein bands were so similar that species identification was impossible.

Gabucci and Flego (1976) studied the heat stability of beef, pork and horse albumin by electroimmunodiffusion and found that antigen activity of beef was lost after 15 min heating at $80^{\circ} \mathrm{C}$, pork after $60 \mathrm{~min}$ at $100^{\circ} \mathrm{C}$, and horse after $30 \mathrm{~min}$ at $70^{\circ} \mathrm{C}$.

Krzynowek and Wiggin (1979) were able to achieve identification of species in cooked crabmeat by thin-layer isoelectric focusing. 


\section{APPENDIX B}

SDS-Polyacrylamide gel electrophoresis for identification and differentiation of species in cooked meat by vertical plate gel electrophoresis. 
SDS-Polyacrylamide gel electrophoresis for identification and differentiation of species in cooked meat by vertical plate gel electrophoresis.

Electrophoresis in polyacrylamide gel electrophoresis in the presence of the anionic detergent sodium dodecyl sulfate is a widely used technique in detection and idendification of protein. Since research on the effect of cooking meats has successfully used SDS-polyacrylamide gel for separation and identification of the denatured serum proteins (Lee et ál., 1974; Mafinen et al., 1979 and Calderoni and Bazan, 1980), and it appeared to be a good procedure to try for analysis of cooked meats. Therefore SDS-polyacrylamide gel electrophoresis was performed according to $0 \mathrm{gita}$ and Markert (1979) with some modifications as shown in Table 2.

Table 2

Stock Solutions Used in Electrophoresis

I: Stock solutions for running ge 1:

IA: Acrylamide-bis solution:

Acrylamide

Bis $39.0 \mathrm{~g}$

Glycerol

$\mathrm{H}_{2} \mathrm{O}$ to make

$1.0 \mathrm{~g}$

$20.0 \mathrm{ml}$

$100.0 \mathrm{ml}$

IB: Buffer solution:

Tris-HC1-SDS buffer (1.5M Tris)

$\begin{array}{lr}\text { Tris } & 18.3 \mathrm{~g} \\ \mathrm{HC} \text { ( conc.) } & 6.0 \mathrm{ml} \\ 10 \% \text { SDS solution } & 4.0 \ldots 1 \\ \mathrm{H}_{2} \mathrm{O} \text { to make } & 100.0 \mathrm{ml}\end{array}$


IC: $0.4 \%(w / v)$ APS solution

$$
\begin{array}{lr}
\text { Ammonium persulphate } & 0.4 \mathrm{~g} \\
\mathrm{H}_{2} \mathrm{O} \text { to make } & 100.0 \mathrm{ml}
\end{array}
$$

ID: $0.8 \%(v / v)$ TEMED solution

$$
\begin{array}{lr}
\text { TEMED } & 0.8 \mathrm{ml} \\
\mathrm{H}_{2} \mathrm{O} \text { to make } & 100.0 \mathrm{ml}
\end{array}
$$

II: Stock solution for stacking gel

IIA - Acrylamide-bis solution

$\begin{array}{lr}\text { Acrylamide } & 38.0 \mathrm{~g} \\ \mathrm{Bis} & 2.0 \mathrm{~g} \\ \mathrm{G} \text { iycerol } & 20.0 \mathrm{ml} \\ \mathrm{H}_{2} \mathrm{O} \text { to make } & 100.0 \mathrm{ml}\end{array}$

IIB - Tris-HCT-SDS buffer (0.50M tris)
Tris
$\mathrm{HC} 1$ (conc.)
$10 \%$ SDS
$\mathrm{H}_{2} \mathrm{O}$ to make
$3.0 \mathrm{~g}$
$2.0 \mathrm{ml}$
$4.0 \mathrm{ml}$ $100.0 \mathrm{ml}$

IIC and IID as IC and ID.

III: Electrode Buffer ( $\mathrm{pH} 8.3$ )

$$
\begin{array}{cc}
\text { IIIA - Tris-glycine-SDS buffer } & (0.025 \mathrm{M} \text { tris) } \\
\text { Tris } & 3.0 \mathrm{~g} \\
\text { Glycine } & 14.4 \mathrm{~g} \\
10 \% \text { SDS } & 10.0 \mathrm{ml} \\
\mathrm{H}_{2} \mathrm{O} \text { to make } & 1.0 \mathrm{liter}
\end{array}
$$

IV: Stock solution used in sample preparation

$2.5 \%$ SDS for treating samples

$0.5 \mathrm{M}$ Tris-HCl buffer ( $\mathrm{pH} 6.8$ ) $10 \%$ SDS solution Glycerine

Mercaptoethanol

$$
\begin{array}{r}
3.0 \mathrm{ml} \\
5.0 \mathrm{ml} \\
10.0 \mathrm{ml} \\
2.0 \mathrm{ml}
\end{array}
$$

Bromophenol blue solutio.. (0.00\%)

$$
\begin{aligned}
& 1 \% \text { BrB Methanol } \\
& \mathrm{H}_{2} \mathrm{O}
\end{aligned}
$$$$
0.5 \mathrm{ml}
$$$$
100.0 \mathrm{ml}
$$

\section{Composition of running gels}

Stock solutions of IA, IB, IC, and $\mathrm{H}_{2} \mathrm{O}$ were mixed in the proportions as given in Table 2. The proportions of 
of the IA solution to water were varied to give different gel concentrations up to $20 \%$ acrylamide gel (Table 3 ), then ID solution was added.

Preparation of the stacking gel. - The stacking gel mixture was prepared by mixing the solution as given in Table 3. A $4 \%$ acrylamide stacking gel was optional for nearly all experiments.

Preparation of the sample. - Cooked beef, lamb, pork and horse meats were prepared as described by 0gita and Markert (1979).

Gel protein staining and destaining. - The gel was stained for 1 hour at $25^{\circ} \mathrm{C}$ with a $0.1 \%$ Coomassie brilliant blue solution freshly made up in 50\% trichloroacetic acid (TCA) and then destained by repeated washing in $10 \%$ acetic acid for several times until the gel became clear.

\section{Procedure}

A. Prior to assembling of the EC-470 vertical gel cell, coat each gasket with approximately $2.5 \mathrm{ml}$ molten agarose. Assemble cell and place in $45^{\circ}$ angle. Pour running gel into gel slab area, overlay carefully with distilled water. Allow 40 minutes for complete polymerization then pour off distilled water.

B. Stand cell in horizontal position. Pour stacking gel into gel slab area and insert the slot form. 
Allow to get for 50 minutes, then connect the cooling plates to the circulating water bath at $4^{\circ} \mathrm{C}$ and turn it on.

C. Remove the excess gel above the slot form, place the cell in a vertical position, and fill the upper electrode chamber with electrode buffer. Carefully remove the slot form and add the remaining electrode buffer to the cell.

D. Add $5 \mathrm{ml}$ of $0.001 \%$ bromophenol blue dye solution to the upper electrode chamber. Connect the electrophoresis cell to the power supply with lower electrode as positive.

E. Carefully add $50 \mathrm{ul}(0.05 \mathrm{ml})$ of the sample to the cell. Turn the power on, and apply $400 \mathrm{~V}$ until the front is migrated $10 \mathrm{~cm}$ from the bottom of the slots.

F. Turn off the power and disconnect the cell. Drain off the electrode buffer and disassemble the cell. Remove the gel and stain it and destain it. 
Table 3

Comparison of Polyacrylamide Gel of Different Concentrations

\begin{tabular}{|c|c|c|c|c|c|c|c|c|c|c|c|}
\hline \multicolumn{5}{|c|}{ Composition of Running Gels* } & \multirow{2}{*}{$\mathrm{H}_{2} \mathrm{O}(\mathrm{ml})$} & \multicolumn{6}{|c|}{ Composition of Running Gels* } \\
\hline Percentage & ge 1 & Stock & solution & $I A(m I)$ & & Percentage & ge 1 & Stock & solution & I I A & $\mathrm{H}_{2} \mathrm{O}$ \\
\hline 3 & & & 1.5 & & 8.5 & 3 & & & 1.5 & & 8.5 \\
\hline 4 & & & 2.0 & & 8.0 & 3.5 & & & 1.75 & & 8.25 \\
\hline 5 & & & 2.5 & & 7.5 & 4.0 & & & 2.0 & & 8.00 \\
\hline 6 & & & 3.0 & & 7.0 & 4.5 & & & 2.25 & & 7.75 \\
\hline 7 & & & 3.5 & & 6.5 & 5.0 & & & $<.5$ & & 7.50 \\
\hline 8 & & & 4.0 & & 6.0 & 5.5 & & & 2.75 & & 7.25 \\
\hline 9 & & & 4.5 & & 5.5 & 6.0 & & & 3.0 & & 7.00 \\
\hline 10 & & & 5 & & 5 & & & & & & \\
\hline 11 & & & 5.5 & & 4.5 & & & & & & \\
\hline 12 & & & 6.0 & & 4.00 & & & & & & \\
\hline 13 & & & 6.5 & & 3.5 & & & & & & \\
\hline
\end{tabular}

*In preparation each concentration of the gel according to these tables. Aliquots of solutions IB, IC, and ID are also added in t..e ratio of $5 \mathrm{ml}$ of IB, $2.5 \mathrm{ml}$ of IC and $2.5 \mathrm{ml}$ of ID. 


\section{RESULTS ND DISCUSSION}

SDS was tried as the procedure for separation and identification of cooked meats. The meat extracted with this method and also the meat which was extracted with SDS (SDS1, SDS-2, SDS-3, SUM and SM) in the initial trials for protein solubilization in order to choose an extraction and applying procedure for cooked meats were applied to this method using $7 \%$ running gel and $4 \%$ stacking gel. After staining and destaining, no bands appeared. This could be related to one of the following problems which have been studied and been associated with SDS. Stoklosa and Latz (1974) indicated that it was necessary to add SDS only to sample solutions. In 1975 they found that the amount of SDS added to sample solutions had a crucial effect on the electrophoretic behavior of protein bands. Nelles and Bamburg (1976) reported that the presence of a small amount of SDS in the upper buffer chamber was necessary to obtain decent results using SDS-polyacrylamide gel electrophoresis.

Kuba et al. (1979) found that the gel concentration had a significant effect on the electrophoresis of SDS modified proteins added in SDS-polyacrylamide gel electrophoresis or could be a staining problem, such as time, amount or kind or chemical resources. Because SDS dissociates the protein into subunits and completely unfolds each polypeptide chain 
to form a long, rod-like SDS-polypeptide complex (Lehninger, 1976), 9 percent and $12 \%$ running ge 1 have been tried, but also with no resolution. 


\section{APPENDIX C}

Polyacrylamide gel electrofocusing for identification and differentiation of species in cooked meat by vertical plate gel electrophoresis. 
Recently more interest has centered on isoelectric focusing in polyacrylamide gels either in disc or slab in detection and identification of protein herefore polyacrylamide gel electrofocusing as recommended by E-C Apparatus Corporation was tried with some modification as follows:

\section{Solution for electrofocusing}

plug gel solution - (10\% cyanogum 41$)$

cyanogum-41

distilled water to TMEP

AP
$10.0 \mathrm{~g}$

$100.0 \mathrm{ml}$

$0.1 \mathrm{ml}$

$100.0 \mathrm{mg}$

running gel solution - ( $5 \%$ cyanogum with $1.3 \%$ ampholyte)

cyanogum-41

$40 \%$ ampholyte solution

water to

TMED

AP
$3.0 \mathrm{~g}$

$2.0 \mathrm{ml}$

$60.0 \mathrm{ml}$

$\begin{array}{lll}0 & 4 & \mathrm{~m} 1\end{array}$

$0.0 u \mathrm{~g}$

gasket seal material - $(0.5 \%$ agarose $)$

agarose

distilled water to
$0.05 \mathrm{~g}$

$10.0 \mathrm{~m} 1$

Sample preparation

The samples were prepared as described previously employing the optimum extraction method developed, BGU

Electrode solutions

a) Anode (lower compartment) $1 \mathrm{M}_{3} \mathrm{H} \mathrm{PO}_{4}$

b) Cathode (upper compartment) $1 \mathrm{M} \mathrm{NaOH}$ 
Overlay solution

$10 \%$ ampholyte

Fixation solution

methanol

glacial acetic acid water to

$900 \mathrm{ml}$

$20 \mathrm{ml}$

21

Staining solution - $(0.05 \%)$

Coomassie Brilliant Blue R-250 or G-250 Fixation solution

$0.5 \mathrm{~g}$

$100 \mathrm{ml}$

A. Prior to assembly of the EC 470 vertical gel cell, coat each gasket with approximately $2.5 \mathrm{ml}$ molten agarose. Assemble cell and place in $45^{\circ}$ angle. Add catalysts to $100 \mathrm{ml}$ of $10 \%$ gel plug solution and pour into gel slab area. Overlay carefully with the distilled water. Allow 30 minutes for complete polymerization.

B. Stand cell in vertical position. Test plug and gasket seal by filling gel area with distilled water. Observe if level is maintained. If not, place cell in $45^{\circ}$ after pouring off distilled water and add $2 \mathrm{ml}$ of gel plug solution as in step A with water overlay. Retest unit. If failure results again, begin at step $A$. If successful in original test or retest, pour off distilled water and shake excess droplets from gel slab area. 
C. Stand cell in vertical position. Add catalysts to running gel solution and pour into gel slab area between cooling plates. Place slot former of desired number of teeth into position. Please note, a small weight on the slot former may be necessary to maintain correct position during polymerization. Allow 30-45 minutes for polymerization.

D. Place overflow tube into top buffer compartment into the hole provided. Plug buffer drain and recirculation holes in upper and lower buffer tanks with polyethylene plugs. Fill upper buffer compartment with distilled water. Carefully remove slot former from gel. Keeping cell upright, drain water completely from upper and lower compartments.

E. Add 25 ul samples to each slot.

F. Carefully add overlay solution to fill each slot.

G. Remove overflow tube and add bottom buffer to lower compartment with a long neck funnel. Add approximately $500 \mathrm{ml}$.

H. After filling lower buffer compartment use a polyethylene plug in lieu of the overflow tube to isolate the bottom buffer from the top buffer. Carefully add top compartment buffer, being sure not to disturb the samp les.

I. Place safety cover on unit. Connect cooling system. Connect power supply with positive lead to the acid containing buffer compartment. 
J. Energize power supply. Using the EC 400 constant power supply, set at 20 watts constant power.

K. After separation, drain and disassemble cell in the usual manner. Remove gel above the plug for fixation and staining.

L. Place gel in one liter of warm, $50^{\circ} \mathrm{C}$, fixation solution for 4 hours minimum.

M. Stain gel for 1 hour or until bands are visible.

N. Destain either electrophoretically or by exhaustive washing in fixation solution. 


\section{RESULTS AND DISCUSSION}

Polyacrylamide gel electrofocusing procedure as recommended by E-C Apparatus Corporation was tried with some modification. Initially the heat generation proved excessive after short time of the run at the recommended 20 watts $(w)$. So, the run was repeated using $10 \mathrm{~W}$ but heat generation proved excessive after a period of time and therefore, the power was cut to $2.5 \mathrm{~W}$. Even so, there was still a small heat effect on the gel. Figure 9 shows polyacrylamide gel electrofocusing of raw, cooked (beef, pork, lamb and horse meats) and canned meat (corned beef and mixture of pork and ham). It shows no migration or bands, and that may be because of the thickness of the gel which generates heat or because the sample contained salt, which contributed to generaced heat, or both. Also it could be a problem caused by oxygen generated at the anode. This is partially dissolved in the medium, and may oxidize the SH-groups of protein. (Goal et al., 1980).

An overview ot the times for running, fixing, staining, and destaining of electrophoresis and isoelectric focu.ing in polyacrylamide gel is shown in Table 4 . These results indicated that electrophoresis is less consuming of time and more applicable for routine work. 


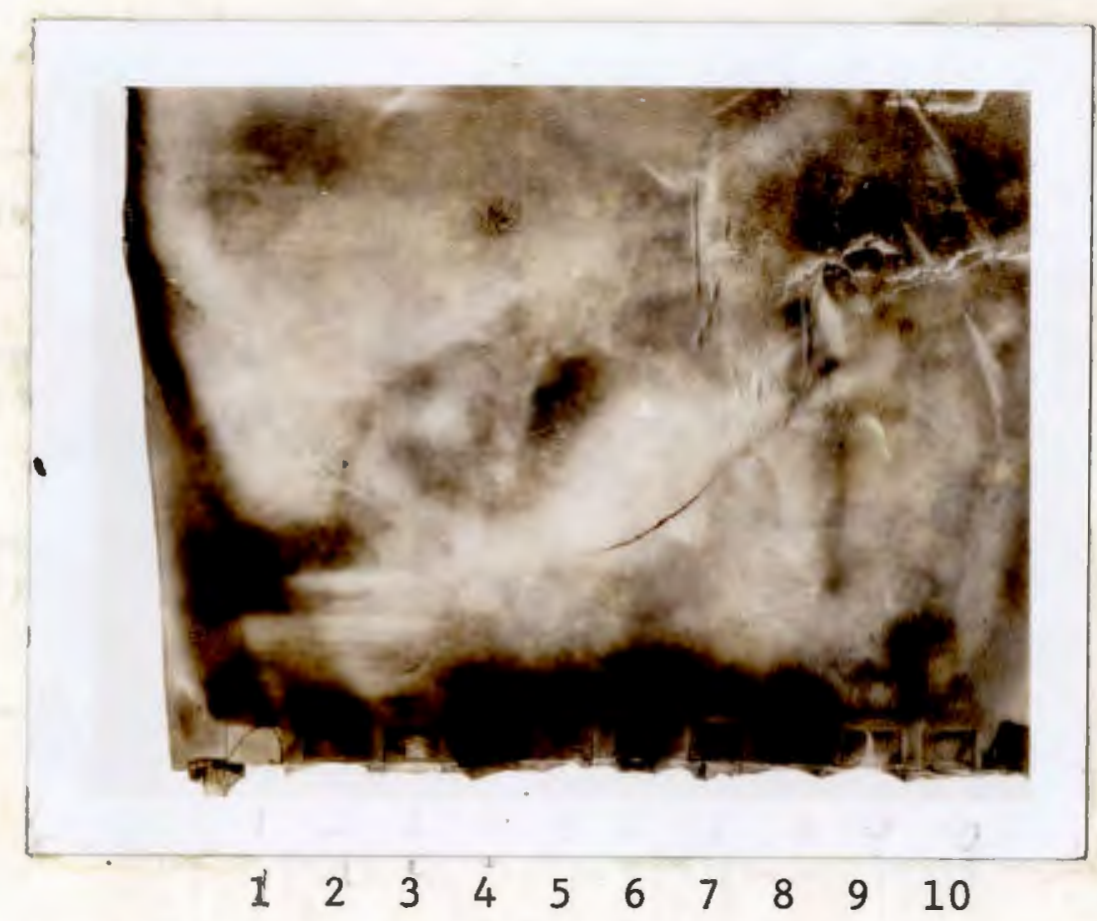

Figure 9. Polyacrylamide gel electrofocusing of raw, cooked (at $75^{\circ}$ ) and canned meats.

1. Corned beef, 2. raw beef, 3. cooked beef, 4. raw pork, 5. cooked pork, 6. raw lamb, 7. cooked lamb, 8. raw horse meat, 9. cooked horse meat, 10, canned pork and ham. 
Table 4

Time in Hours for Electrophores is and Isoelectric

Focusing in Polyacrylamide Gel

\begin{tabular}{lcccrc}
\hline $\begin{array}{l}\text { Technique } \\
\text { Time }\end{array}$ & $\begin{array}{c}\text { Running } \\
\text { Tixing }\end{array}$ & Staining & Destaining & $\begin{array}{c}\text { Total } \\
\text { Time }\end{array}$ \\
$\begin{array}{l}\text { Electro- } \\
\text { phoresis }\end{array}$ & 2 & - & $0 . \frac{1}{4}$ & $8-10$ & $10 \cdot \frac{1}{4}-12 \cdot \frac{1}{4}$ \\
$\begin{array}{l}\text { Isoelectro- } \\
\text { focusing }\end{array}$ & $6-24$ & 6 & $1-10$ & $4-6$ & $17-46$ \\
\hline
\end{tabular}


53

APPENDIX D

Bibliography of the Complete Thesis 


\section{B I BL I OGRAPHY}

Ahmadi, B. 1979. Recovery of protein from sodium dodecyl sulfate-polyacrylamide gels. Anal. Biochem. 97:229.

Caldaroni, H.A. and Bazan, N.G. 1980. Quantitative determination of low-salt soluble protein patterns of bovine muscles cooked at different temperature oy sodium dodecyl sulfate-polyacrylamide gel electropheresis. J. Food Sci. 45:901.

Coduri, R.J., Bonatti, K. and Simpson, K.L. 1979. Fish and other marine products. Application of vertical plate gel electropooresis to the separation of pigmented and nonpigmented trout and salmon species. J. Assoc. Off. Ana 1. Chem. 62:269.

Coduri, R.J. and Rand, A.G. 1972a. Vertical plate gel electrophoresis for the differentiation of $m$ at species. J. Assoc. Off. Anal. Chem. 55:461.

Coduri, R.J. and Rand, A.G. 1972a. Vertical plate gel electrophoresis for the differentiation of meat species. J. Assoc. Off. Anal. Chem. 55:461.

Coduri, R.J. and Rand, A.G. 1972b. Vertical plate gel electrophoresis for the differentiat. on of $\mathrm{fish}$ and shellfish species. J. Assoc. Off. Anal. Chem. 55:464.

Cohen, E.H. 1966. Protein changes related to ham processing temperatures. 1. Effect of time-temperature on amount and composition of soluble proteins. J. Food Sci. $31: 746$.

Cohen. E.H. 1969. Determination of acid phosphatase activity in canned ham as an indicator of temperatures attained during cooking. Food Technol. 23:961.

Davis, B.J. 1964. Disc electrophoresis. II. Method and application to human serum proteins. Ann. N.Y. Acad Sci. 121:404.

Deschrreider, A.R. and Meaux, R. 1974. Polyacrylamide gel electrophoresis of meat proteins. Industries Alimentaires et Agricales. 91:101 [Food Sci. Technol. Abstr. 2 so $182(1975)]$.

Doesburg: J.J. and Papendrof, D. 1969. Determination of degree of heating of fish muscle. J. Food Technol. $4: 17$. 
Fennema, R.0. 1976. Principle of Food Science. Part I. Food Chemistry. Marcel Dekker Inc. New York.

Fogg, N.E. and Harrison, D.L. 1975. Relationship of electrophoretic patterns and selected characteristics of bovine skeletal muscle and internal temperature. J. Food Sci. 40:28.

Gaa1, O., Medgyesi, G.A. and Vereczykey, L. 1980. Electrophoresis in the separation of biological macromolecules. John Wiley and Sons, and Chichester.

Gabucci, G. and Flego, L. 1976. Application of immunological analysis for identifying the species of origin of raw and cooked meat products. Heat stability of beef, pork, and horse albumin measured by electroimmunodiffusion. Bollettino dei Laboratori Chimici Provinciali. 27: 236 [Food Sci. Technol. Abstr. 550862 (1977)].

Heidelbaugh, N.D. and Graves, J.H. 1968. Effects of some techniques applicable in food processing on the infectivity of foot-and-mouth disease virus. Food Techno1. 22:234.

Helmke, A. and Froning, G.W. 1971. The effect of end-point cooking temperature and storage on the color of turkey meat. Poultry Sci. 50:1832.

Krzynowek, J. and Wiggin, K. 1979. Identification of species in cooked crabmeat by thin layer isoelectric focusing. J. Assoc. Off. Anal. Chem. 62:630.

Kubo, K., Isemura, T. and Takagi, T. 1975. Electrophoretic properties of sodium dodecyl sulfate and related changes in its concentration in SDS-polyacrylamide gel electrophoresis. J. Biochem. 78:349.

Laakkonen, E., Sherbon, J.W. and Wellington, G.W. 1970. Low temperature, long-time heating of bovine muscle. J. Food Sci. 35:178.

Lee, Y.B., Rickonsrud, D.A., Hagberg, E.C. and Briskey, E.J. 1974. Application of SDS-acrylamide gel electrophoresis for determination of the maximum temperature to which bovine muscles have been cooked. J. Food Sci. $39: 428$.

Lehninger, A.L. 1976. Biochemistry. Worth Publishers, Inc. 
Makanichi, A., Wreede, I. de; Stegemann, H., Henert, H.H. 1979. Solubility and gel electrophoretic patterns of heat denatured proteins, even from samples containing starch, after treatment with sodium dodecyl sulphate. Zeitschrift fur Lebensmittle-untersuchung und Forschung. 168:282 [Food Sci. Technol. Abstr. 9 A0651 (1979)]

Mancuso, V.M. 1964. Protein typing of some authentic fish species by disc electrophoresis. J. Asso. Off. Anal. Chem. 47, 5:841.

Nakanichi, M. and Raymond, S. 1962. Acrylamide gel electrophoresis of hemoglobins. Clin. Chem. 9:135.

Nello, L.P. and Bamburg, J.R. 1975. Rapid visualization of protein-dodecyl sulfate complex in polyacrylamide gels. Ana1. Biochem. 73:522.

Ogita, Z. and Markert, C.L. 1979. A miniaturized system for electrophoresis on polyacrylamide gels. Anal. Biochem. 99:233.

Ornstein, L. 1964. Disc electrophoresis. I. Background and theory. Ann. N.Y. Acad. Sci. 121:321.

Payne, W.R. 1963. Protein typing of fish, pork and beef by disc electrophoresis. J. Assoc. Off. Anal. Chem. $46: 1003$.

Raymond, S. 1964. Acrylamide gel electrophoresis. Ann. N.Y. Acad. Sci. 121:350.

Stoklosa, J.T. and Latz, H.W. 1974. Molecular weight determinations of proteins by polyacrylamide gel electrophoresis with sodium dodecyl sulfate in just the sample solution. Biochem. Biophys. Res. Commun. 58:74.

Stocklosa, J.T. and Latz, H.W. 1975. Electrophoretic behavior of protein dodecyl sulfate complexes in the presence of various amounts of sodium dodecyl sulfate. Anal. Biochem. $68: 358$.

Thomas, E.L., Nielsen, A.J and Olson, J.C. 1955. HydroIytic rancidity in milk - a simplified method for estimating the extent of its development. Am. Milk Rev., $17: 50$.

Wilson, Curtis M. 1979. Studies and Critiques of Amido black $10 B$, Coomassie Blue $R$, and fast green FCF as stains for proteins after polyacrylamide gel electrophoresis. Anal. Biochem. 96:263. 